Winter Meeting - Joint meeting between the Nutrition Society and the Royal Society of Medicine, 11-12 December 2012, Dietary Strategies for the Management of Cardiovascular Risk

\title{
Serum 25-Hydroxyvitamin D concentrations in relation to dietary fat intake and body fat concentration in Caucasian and Asian women
}

\author{
A. Salim, S. A. Lanham-New and O. A. Hakim \\ Faculty of Health and Medical Sciences, University of Surrey, Guildford GU2 7XH, UK
}

Growing obesity rates cultivated by transitions in lifestyle factors has manufactured a plethora of related non-communicable illnesses including cardio-metabolic disease. Although classically associated with skeletal health, the discovery of vitamin D receptors in numerous non-skeletal tissues and cells (including adipose) ${ }^{(1)}$ combined with the association between serum $25-\mathrm{Hydroxyvitamin} \mathrm{D}(25(\mathrm{OH}) \mathrm{D})$ and diseases commonly allied with obesity ${ }^{(2)}$, supports $25(\mathrm{OH}) \mathrm{D}$ association with dietary fat and adiposity.

This study aimed to examine the relationship between intake of various dietary fats and body fat composition with serum $25(\mathrm{OH}) \mathrm{D}$ in 110 pre- and postmenopausal Caucasian and Asian women. All anthropometric measures, dietary data and serum 25(OH)D levels were provided by the D-FINES study (Vitamin D, Food Intake, Nutrition and Exposure to Sunlight in Southern England) conducted at the University of Surrey. All subject anthropometric, fat intake and serum $25(\overline{\mathrm{OH}}) \mathrm{D}$ measurements were statistically analysed, and mean fat intakes were compared against UK recommendations. Spearman's correlation coefficient was used to examine the relationship between serum $25(\mathrm{OH}) \mathrm{D}$, anthropometry, and dietary fat intake in all ethnic and menopausal sub-groups.

The results illustrate no significant difference between any anthropometric variable other than BMI in postmenopausal women of both ethnicities $(P=0.005)$, possibly a result of low subject number. Furthermore, no significant difference was observed in consumption of any dietary fat between sub-groups, likely due to limited subject response to the dietary assessment. However, serum $25(\mathrm{OH}) \mathrm{D}$ levels were significantly lower in both pre- and postmenopausal Asian women when compared to Caucasian women $(P=0.000)$. The table below displays a significant negative association linking serum $25(\mathrm{OH}) \mathrm{D}$ with weight and BMI in postmenopausal Caucasian women only. Statistical analysis found no significant association between $25(\mathrm{OH}) \mathrm{D}$ and fat intakes in any of the sub-groups.

\begin{tabular}{|c|c|c|c|c|c|}
\hline \multirow[b]{2}{*}{ Ethnicity } & \multirow[b]{2}{*}{ Reproductive status } & \multicolumn{4}{|c|}{ Serum 25(OH)D } \\
\hline & & Standing Height (m) & Weight (kg) & BMI $\left(\mathrm{kg} / \mathrm{m}^{2}\right)$ & Waist to Hip Ratio \\
\hline Caucasian & $\begin{array}{l}\text { Total }(n=74) \\
\text { Premenopausal }(n=18) \\
\text { Postmenopausal }(n=56)\end{array}$ & $\begin{array}{l}0.05 \\
0.22 \\
0.004\end{array}$ & $\begin{array}{l}-0.29 *(P=0.011) \\
0.070 \\
-0.38 * *(P=0.004)\end{array}$ & $\begin{array}{l}-0.29 *(P=0.011) \\
-0.069 \\
-0.35 *(P=0.008)\end{array}$ & $\begin{array}{r}-0.05 \\
0.22 \\
-0.16\end{array}$ \\
\hline Asian & $\begin{array}{l}\text { Total }(n=34) \\
\text { Premenopausal }(n=15) \\
\text { Postmenopausal }(n=19)\end{array}$ & $\begin{array}{r}-0.35 \\
-0.10 \\
0.009\end{array}$ & $\begin{array}{c}0.031 \\
-0.11 \\
0.17\end{array}$ & $\begin{array}{c}0.139 \\
-0.06 \\
0.12\end{array}$ & $\begin{array}{l}-0.18 \\
-0.19 \\
-0.33\end{array}$ \\
\hline
\end{tabular}

*Correlation is significant at the 0.05 level. ** Correlation is significant at the 0.01 level.

Consequently, this study demonstrated serum $25(\mathrm{OH}) \mathrm{D}$ to be associated with weight and BMI, but not fat consumption. It is suggested that deficiency is targeted in Asian women, and further research with a larger sample size is recommended.

1. DeLuca HF (2004) Overview of general physiologic features and functions of vitamin D. American Journal of Clinical Nutrition 80, 1689 S-1696.

2. Pearce SHS and Cheetham TD (2010) Diagnosis and management of vitamin D deficiency. British Medical Journal; 340, b5664. 